\title{
myo-Inositol transport by Salmonella enterica serovar Typhimurium
}

\begin{abstract}
Correspondence
Thilo M. Fuchs

thilo.fuchs@wzw.tum.de
\end{abstract}

Received 8 July 2009

Revised 6 October 2009

Accepted 9 October 2009

\author{
Carsten Kröger, ${ }^{1}$ Jürgen Stolz ${ }^{2}$ and Thilo M. Fuchs ${ }^{1}$
}

\author{
'Zentralinstitut für Ernährungs- und Lebensmittelforschung (ZIEL), Abteilung Mikrobiologie, \\ Technische Universität München, Weihenstephaner Berg 3, D-85350 Freising, Germany \\ ${ }^{2}$ Zentralinstitut für Ernährungs- und Lebensmittelforschung (ZIEL), Abteilung Biochemie, \\ Technische Universität München, Gregor-Mendel-Str. 2, D-85350 Freising, Germany
}

\section{INTRODUCTION}

myo-Inositol (MI) is a polyol abundant in soil. Its phosphorylated form, inositol hexakisphosphate or phytate, serves as a phosphorus store in plants, but can be utilized by livestock only in the presence of phytases. The capability of an increasing number of micro-organisms to grow on MI as the sole carbon source depends on the presence of a catabolic pathway that results in MI degradation to dihydroxyacetone phosphate, acetyl coenzyme $\mathrm{A}$ and $\mathrm{CO}_{2}$.

Although inositol utilization was investigated extensively at the enzymic level for Enterobacter (Aerobacter) aerogenes decades ago (Anderson \& Magasanik, 1971), the underlying genetics and regulatory mechanisms have been elucidated in most detail for Bacillus subtilis (Miwa \& Fujita, 2001; Yoshida et al., 2004, 1997). In this organism, the iol divergon responsible for MI utilization comprises

Abbreviations: CCCP, carbonyl cyanide m-chlorophenylhydrazone; FRT, FLP recognition target; MFS, major facilitator superfamily; MI, myoinositol; RLU, relative light units.

A supplementary table listing the primers used is available with the online version of this paper.
iolT and the operons iolABCDEFGHIJ and iolRS. IolR acts as a repressor of the iol divergon by binding to the operator sites in the absence of MI. An intermediate of MI degradation, 2-deoxy-5-keto-D-gluconic acid 6-phosphate, has been shown to antagonize IolR binding, thus inducing the expression of iol genes (Yoshida et al., 2008, 1999). Two proteins belonging to the major facilitator superfamily (MFS), IolT and IolF, have been identified as the major and minor inositol transporters of B. subtilis, and IolR has been revealed to inhibit the transcription of iolT (Yoshida et al., 2002). MI degradation has also been studied in Corynebacterium glutamicum (Krings et al., 2006), Clostridium perfringens (Kawsar et al., 2004) and Lactobacillus casei (Yebra et al., 2007).

So far, several Gram-negative genera have been demonstrated to utilize the polyol MI. These include species from the genera Klebsiella, Caulobacter, Rhizobium, Sinorhizobium, Pseudomonas, Yersinia, Salmonella and Serratia (Berman \& Magasanik, 1966; Boutte et al., 2008; Fry et al., 2001; Gauchat-Feiss et al., 1985; Kröger \& Fuchs, 2009; Legakis et al., 1976; Primrose \& Ronson, 1980; Reber et al., 1977). A comparison of the respective gene clusters reveals a high variability of their chromosomal organiza- 
tion. In Salmonella enterica serovar Typhimurium, the genes required for MI degradation are located on a $22.6 \mathrm{~kb}$ genomic island (GEI4417/4436). Identical islands are present only in the genomes of the $S$. enterica serovars Paratyphi B, Saintpaul, Weltevreden, Agona and Virchow, and are absent in serovars Typhi, Paratyphi A, Choleraesuis and many others, indicating that the utilization of MI is not a common capability of Salmonella strains. Interestingly, this MI utilization island is not restricted to salmonellae; we identified a nearly identical gene cluster lacking homologues of iolI2 and iolH in the genome of Escherichia coli ED1a (NC_011745.1). In this strain, the island is flanked by two transposase-encoding genes, strongly suggesting that its distribution among Gramnegative bacteria is due to horizontal gene transfer. The genomic island of $S$. enterica includes five transcriptional units encoding enzymes involved in MI utilization, and these are induced in the presence of MI. In rich medium, the negative regulator IolR represses all but one promoter of the iol divergon, including its own.

A total of 20 genes are located on GEI4417/4436, but a functional role has been described only for eight of them (Kröger \& Fuchs, 2009). Four genes, STM4418, STM4419,
STM4428 and STM4434, encode putative, as yet uncharacterized, permeases. Their role in MI transport was investigated here by the construction of in-frame deletion mutants and complementing plasmids. The transcriptional activity of two putative transporter genes (STM4418 and STM4419), as well as the regulatory role of IolR, were monitored using the luciferase reporter system and bandshift assays. Uptake of myo-[1,2-[ $\left.\left.{ }^{3} \mathrm{H}\right](\mathrm{N})\right]$ inositol was investigated in $S$. enterica serovar Typhimurium strain 14028, in mutant strains lacking the putative transporters, and in E. coli cells expressing STM4418 and STM4419, revealing a transport activity of STM4418, now termed IolT1. This study describes for the first time, to our knowledge, an MI transporter of a Gram-negative bacterium.

\section{METHODS}

Bacterial strains, plasmids and growth conditions. Bacterial strains and plasmids used in this study are listed in Table 1. S. enterica serovar Typhimurium and E. coli cultures were grown in Luria-Bertani (LB) broth (10 g tryptone $1^{-1}, 5 \mathrm{~g}$ yeast extract $1^{-1}$, $5 \mathrm{~g} \mathrm{NaCl} \mathrm{l}^{-1}$ ) or in minimal medium [MM; M9 medium supplemented with $2 \mathrm{mM} \mathrm{MgSO}_{4}, 0.1 \mathrm{mM} \mathrm{CaCl}_{2}$ and $55.5 \mathrm{mM}$

Table 1. Strains and plasmids used in this study

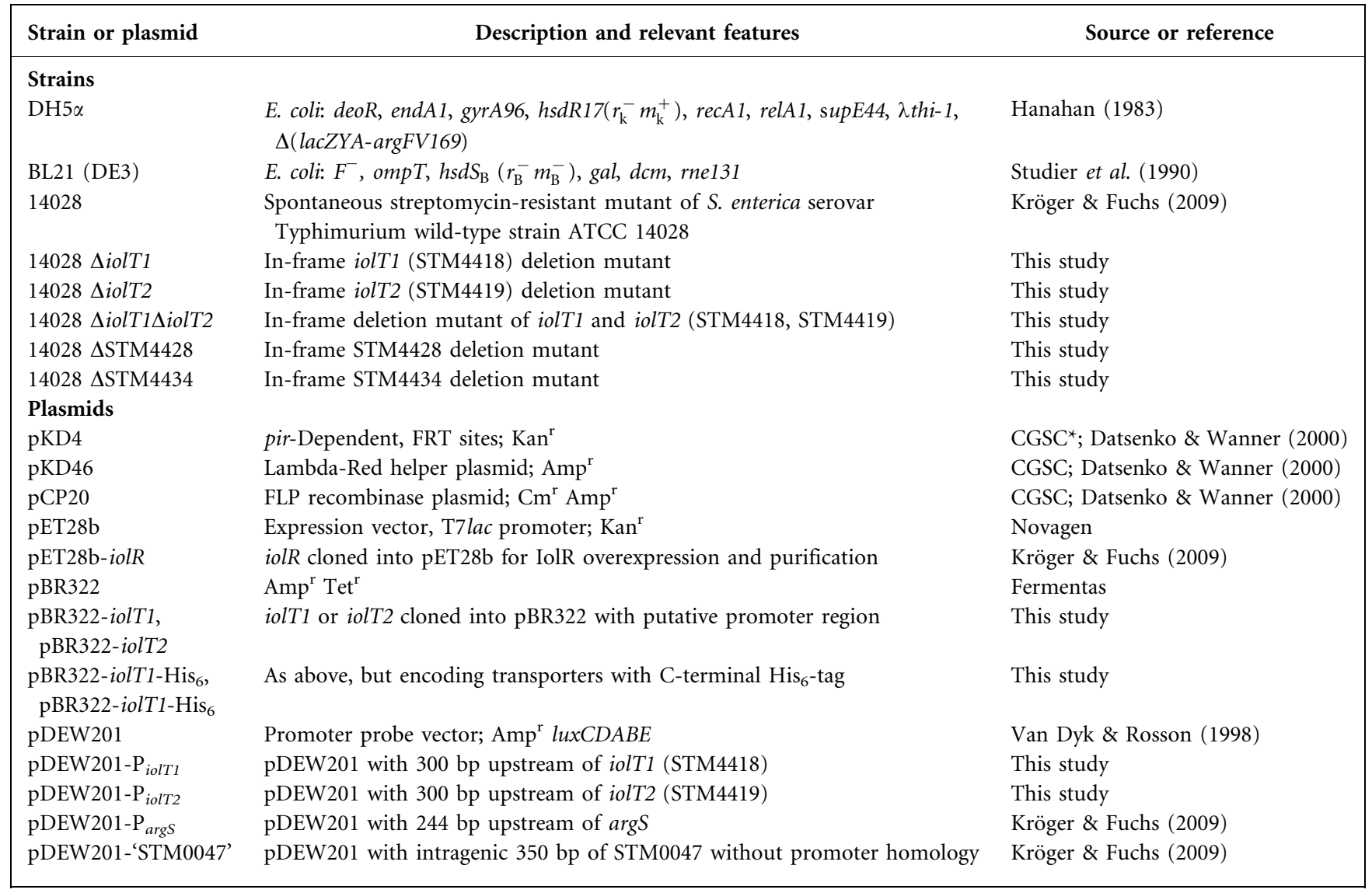

${ }^{\star}$ CGSC, Coli Genetic Stock Center, Yale University. 
(1\%) MI, glucose, fructose, arabinose, xylose, glycerol or sorbitol]. For plasmid maintenance, the media were supplemented with the following antibiotics: ampicillin $\left(150 \mu \mathrm{g} \mathrm{ml}^{-1}\right)$, kanamycin $(50 \mu \mathrm{g}$ $\left.\mathrm{ml}^{-1}\right)$, chloramphenicol $\left(25 \mu \mathrm{g} \mathrm{m}^{-1}\right)$ or streptomycin $(50 \mu \mathrm{g}$ $\left.\mathrm{ml}^{-1}\right)$. For solid media, $1.5 \%$ agar $(\mathrm{w} / \mathrm{v})$ was added. For all growth and promoter probe experiments, bacterial strains were grown in LB medium overnight at $37^{\circ} \mathrm{C}$, washed twice in PBS and then adjusted to $\mathrm{OD}_{600} 0.005$ in the desired liquid growth medium, or streaked on agar plates. Growth curves were obtained from bacterial cultures incubated at $37{ }^{\circ} \mathrm{C}$ under vigorous shaking in $250 \mathrm{ml}$ flasks with $50 \mathrm{ml} \mathrm{MM}$. $\mathrm{OD}_{600}$ was measured at the time interval indicated.

Standard procedures. DNA manipulations and isolation of chromosomal or plasmid DNA were performed according to standard protocols (Sambrook \& Russell, 2001), and following the manufacturers' instructions. Plasmid DNA was transformed via electroporation by using a Bio-Rad Gene Pulser II as recommended by the manufacturer and as described previously (Klumpp \& Fuchs, 2007). PCRs were carried out with Taq polymerase (Fermentas). As template for PCR, chromosomal DNA, plasmid DNA or cells from a single colony were used. Oligonucleotides synthesized for PCRs are listed in Supplementary Table S1. S. enterica serovar Typhimurium gene numbers refer to the LT2 annotation (NC 003197). The homepages http://enterix.cbcb.umd.edu/ and http://www.microbesonline.org/ were used to determine the distribution of $S$. enterica serovar Typhimurium ORFs in the genomes of Gram-negative species. Promoter sequences located upstream of the identified genes were predicted with BPROM (http://www.softberry.com/), and transmembrane domains with TOPCONS (http://topcons.cbr.su.se/). The cladogram was constructed with TREECON (Van de Peer \& De Wachter, 1994).

Construction of deletion mutants and recombinant plasmids. In-frame deletion mutants of iolT1 (STM4418), iolT2 (STM4419), STM4428 and STM4434 were constructed by the one-step method based on the phage $\lambda$ Red recombinase (Datsenko \& Wanner, 2000). Briefly, PCR products comprising the kanamycin resistance cassette of plasmid pKD4, including the flanking FLP recognition target (FRT) sites, were generated using pairs of $70 \mathrm{nt}$ primers that included $20 \mathrm{nt}$ priming sequences for $\mathrm{pKD} 4$ as template DNA. Homology extensions of $50 \mathrm{bp}$ overlapped $18 \mathrm{nt}$ of the $5^{\prime}$ end and $36 \mathrm{nt}$ of the $3^{\prime}$ end of the target gene (Link et al., 1997). Fragment DNA (500-1000 ng) was transferred into S. enterica serovar Typhimurium strain 14028 cells harbouring plasmid pKD46. Allelic replacement of the target gene by the kanamycin resistance cassette was controlled by PCR, and nonpolar deletion mutants were obtained upon transformation of pCP20. Gene deletions were verified by PCR analysis and DNA sequencing.

To complement deleted genes, the coding sequences of iolT1 (STM4418) and iolT2 (STM4419) plus approximately $300 \mathrm{bp}$ of their upstream region were amplified from chromosomal DNA of strain 14028 with primers listed in Supplementary Table S1. PCR products were digested with EcoRI and SalI (Fermentas) and ligated (T4 DNA ligase, Gibco) into vector pBR322 to generate pBR322-iolT1 and pBR322-iolT2, respectively. The plasmids were verified by PCR, restriction analysis and sequencing. To detect proteins by Western blot analysis, both genes were amplified with primers introducing a C-terminal $\mathrm{His}_{6}$-tag and cloned as described above, resulting in pBR322-iolT1-His 6 and pBR322-iolT2-His 6 .

Cloning of promoter fusions. Putative promoter regions spanning approximately $300 \mathrm{bp}$ upstream of the start codons of the genes iolT1 (STM4418) and iolT2 (STM4419) were amplified from chromosomal DNA of S. enterica serovar Typhimurium 14028 by PCR using the primers listed in Supplementary Table S1. The fragments were then cloned via EcoRI and BamHI (Fermentas) upstream of the promoterless luxCDABE genes into the multiple cloning site of pDEW201. After transformation into E. coli $\mathrm{DH} 5 \alpha$ cells, plasmids containing the correct transcriptional lux fusions were isolated and verified by PCR, restriction analysis and sequencing. pDEW201- $\mathrm{P}_{\text {iolT1 }}$ and pDEW201- $\mathrm{P}_{\text {iolT2 }}$ were transformed into $S$. enterica serovar Typhimurium 14028 and the $\Delta$ iolR mutant strain.

Quantification of promoter activity. Bioluminescence measurements were performed as previously described (Kröger \& Fuchs, 2009). For growth in MM containing either $27.8 \mathrm{mM}(0.5 \%)$ glucose or $55.5 \mathrm{mM}$ MI, bacterial cells were grown at $37{ }^{\circ} \mathrm{C}$ until they reached the late-exponential growth phase, e.g. for $11 \mathrm{~h}$ (glucose) and $70 \mathrm{~h}$ (MI), in $15 \mathrm{ml}$ centrifuge tubes without agitation. At appropriate time points, $200 \mu \mathrm{l}$ of each sample was transferred to a 96 -well plate, and the $\mathrm{OD}_{600}$ and the bioluminescence, measured as relative light units (RLU), were recorded in a Wallac VICTOR ${ }^{3} 1420$ multilabel counter (Perkin Elmer Life Sciences).

Gel mobility shift (GMS) assays. IolR- $\mathrm{His}_{6}$ was overexpressed and purified as previously described (Kröger \& Fuchs, 2009). Briefly, expression of IolR was induced by adding $0.1 \mathrm{mM}$ IPTG when E. coli BL21 cells transformed with pET28b-iolR had reached $\mathrm{OD}_{600} 0.4$. After incubation for $4 \mathrm{~h}$, the cells were harvested and the pellet was resuspended in $1 \mathrm{ml}$ buffer $\mathrm{A}\left(300 \mathrm{mM} \mathrm{NaCl}, 50 \mathrm{mM} \mathrm{Na}_{3} \mathrm{PO}_{4}\right)$. The cells were lysed using a French press (SLM Aminco Instruments), and cell debris was removed by centrifugation at $4{ }^{\circ} \mathrm{C}(20 \mathrm{~min}$, $1.6 \times 10^{4} \mathrm{~g}$ ). After adding $10 \mu \mathrm{l}$ of the protease inhibitor PMSF $(100 \mathrm{mM})$, IolR-His ${ }_{6}$ was purified using TALON metal affinity resin (Clontech Laboratories). A $1 \mathrm{ml}$ volume of the protein extract was mixed with $1 \mathrm{ml}$ resin and incubated for $1 \mathrm{~h}$ at room temperature. The resin was washed and eluted according to the manufacturer's protocol. Fractions containing high amounts of IolR-His 6 were pooled and the buffer was exchanged with GMS buffer [50 mM Tris/ $\mathrm{HCl}, \mathrm{pH}$ 7.5, $50 \mathrm{mM} \mathrm{KCl}, 10 \mathrm{mM} \mathrm{MgCl}$, $0.5 \mathrm{mM}$ EDTA, $10 \%$ (v/v) glycerol] by gel filtration using PD-10 columns (GE Healthcare) (Schaaf \& Bott, 2007). The protein concentration was determined using RotiQuant solution (Carl Roth) based on the method of Bradford (1976), and the purity of eluted fractions was analysed by separation on a $15 \%$ SDS-polyacrylamide gel.

For GMS assays, putative promoter regions of iolT1, iolT2, iolR, iolH and $\arg S$ as competitor DNA were amplified with oligonucleotides listed in Supplementary Table S1, and 100 ng DNA was mixed with increasing amounts of purified IolR-His ${ }_{6}$ in GMS buffer. After incubation for $45 \mathrm{~min}$ at room temperature, the samples were loaded on a $9.5 \%$ native polyacrylamide gel prepared in $1 \times$ Tris/ borate/EDTA buffer and separated at $120 \mathrm{~V}$ for $3 \mathrm{~h}$. DNA was then stained with ethidium bromide solution and visualized by UV irradiation.

Membrane isolation and Western blot analysis. $\mathrm{DH} 5 \alpha$ cells transformed with pBR322-iolT1-His ${ }_{6}$ and pBR322-iolT2-His ${ }_{6}$ were grown to stationary phase. Isolation of $E$. coli membranes was then performed as described previously (Kreutzenbeck et al., 2007) but using a French press (SLM Aminco Instruments) to lyse the cells. Protein concentrations were measured using RotiQuant solution. Samples $(15 \mu \mathrm{g})$ of membrane protein were separated on a $12.5 \%$ SDS-polyacrylamide gel, and Western blot analysis of the $\mathrm{His}_{6}$-tagged proteins IolT1 and IolT2 was performed according to standard procedures with 1:1000 diluted monoclonal anti-His ${ }_{6}$ antibodies (dianova) and 1:15000 diluted alkaline phosphatase-conjugated antimouse antibodies (dianova). Phosphatase activity was detected with nitro blue tetrazolium (NBT) and 5-bromo-4-chloro-3-indolyl phosphate $(\mathrm{BCiP})$ as substrates.

Uptake of myo-[1,2-[ $\left.\left.{ }^{3} \mathbf{H}\right](\mathbf{N})\right]$ inositol. E. coli DH5 $\alpha$ cells transformed with pBR322-iolT1, pBR322-iolT2 and pBR322 were grown in 
$30 \mathrm{ml} \mathrm{LB}$ medium containing ampicillin $\left(100 \mu \mathrm{g} \mathrm{ml}^{-1}\right)$ to $\mathrm{OD}_{600} 1.0$. Then, $20 \mathrm{ml}$ was harvested by centrifugation $\left(4{ }^{\circ} \mathrm{C}\right.$ and $\left.1 \times 10^{4} \mathrm{~g}\right)$ and resuspended in McIlvaine's buffer [0.1 $\mathrm{M} \mathrm{Na}_{2} \mathrm{HPO}_{4}, 0.05 \mathrm{M}$ citric acid mixed to obtain the desired $\mathrm{pH}$ (McIlvaine, 1921)] to $\mathrm{OD}_{600} 4.0$ and stored on ice. Cell suspension $(250 \mu \mathrm{l})$ was mixed with $230 \mu \mathrm{l}$ McIlvaine's buffer and $12.5 \mu \mathrm{l} 2.2 \mathrm{M}(40 \%)$ glucose, and stirred in a water bath at $37{ }^{\circ} \mathrm{C}$ for $2 \mathrm{~min}$. The protonophore carbonyl cyanide $m$-chlorophenylhydrazone (CCCP) was added 2 min before the start of the experiment at a final concentration of $50 \mu \mathrm{M}$. The uptake experiment was started by adding $7 \mu \mathrm{l}$ of a mixture of unlabelled MI and $m y o-\left[1,2-\left[{ }^{3} \mathrm{H}\right](\mathrm{N})\right]$ inositol [specific activity $30 \mathrm{Ci}(1110 \mathrm{GBq})$ $\mathrm{mmol}^{-1}$; Biotrend]. In experiments to determine the $\mathrm{pH}$ optimum of MI uptake, this mix contained $1 \mathrm{mM}$ unlabelled and $26.67 \mathrm{nM}$ tritiated substrate. The $K_{\mathrm{m}}$ value was determined at $\mathrm{pH} 5.5$ with a mix containing the same amount of labelled substrate but decreasing amounts of unlabelled substrate $(1,0.5,0.2$ and $0.1 \mathrm{mM})$. Aliquots of $60 \mu \mathrm{l}$ were removed, rapidly filtered through a Pall GN6 $0.45 \mu \mathrm{m}$ pore-size nitrocellulose filter, washed once with $5 \mathrm{ml} 150 \mathrm{mM} \mathrm{NaCl}$ and transferred to a scintillation vial. After addition of $3 \mathrm{ml}$ scintillation cocktail (Carl Roth), the radioactivity associated with the filters was counted in a Perkin Elmer Tri-Carb scintillation counter. The uptake activity was constant for the first $50 \mathrm{~s}$, and this interval was used to determine uptake velocities. Uptake experiments with S. enterica serovar Typhimurium were performed in a similar manner, but cells were cultivated in MM with $55.5 \mathrm{mM}$ MI.

\section{RESULTS}

\section{Identification of two putative transporters involved in MI uptake}

The genomic island GEI4417/4436 of S. enterica serovar Typhimurium responsible for degradation of MI carries four genes (STM4418, STM4419, STM4428 and STM4434), whose products, annotated as permeases or sugar transporters of the MFS, represent candidate MI transporters. Strain 14028 and in-frame deletion mutants of all four putative transporter genes were tested for their ability to grow on MM agar plates, or in liquid MM, containing $55.5 \mathrm{mM}$ MI. The doubling time of the wildtype strain was lower in glucose (growth rate $\mu=0.56 \mathrm{~h}^{-1}$ ) than in MI $\left(\mu=0.37 \mathrm{~h}^{-1}\right)$. In contrast to the mutants 14028 $\Delta$ STM4428 and $14028 \Delta$ STM4434, the deletion of STM4418 or STM4419 resulted in altered growth phenotypes; these genes were therefore named iolT1 (STM4418) and iolT2 (STM4419). The deletion of iolT1 abolished growth in liquid minimal medium containing MI for up to $74 \mathrm{~h}$ (Fig. 1a), and the mutant strain $14028 \Delta$ iolT1 showed
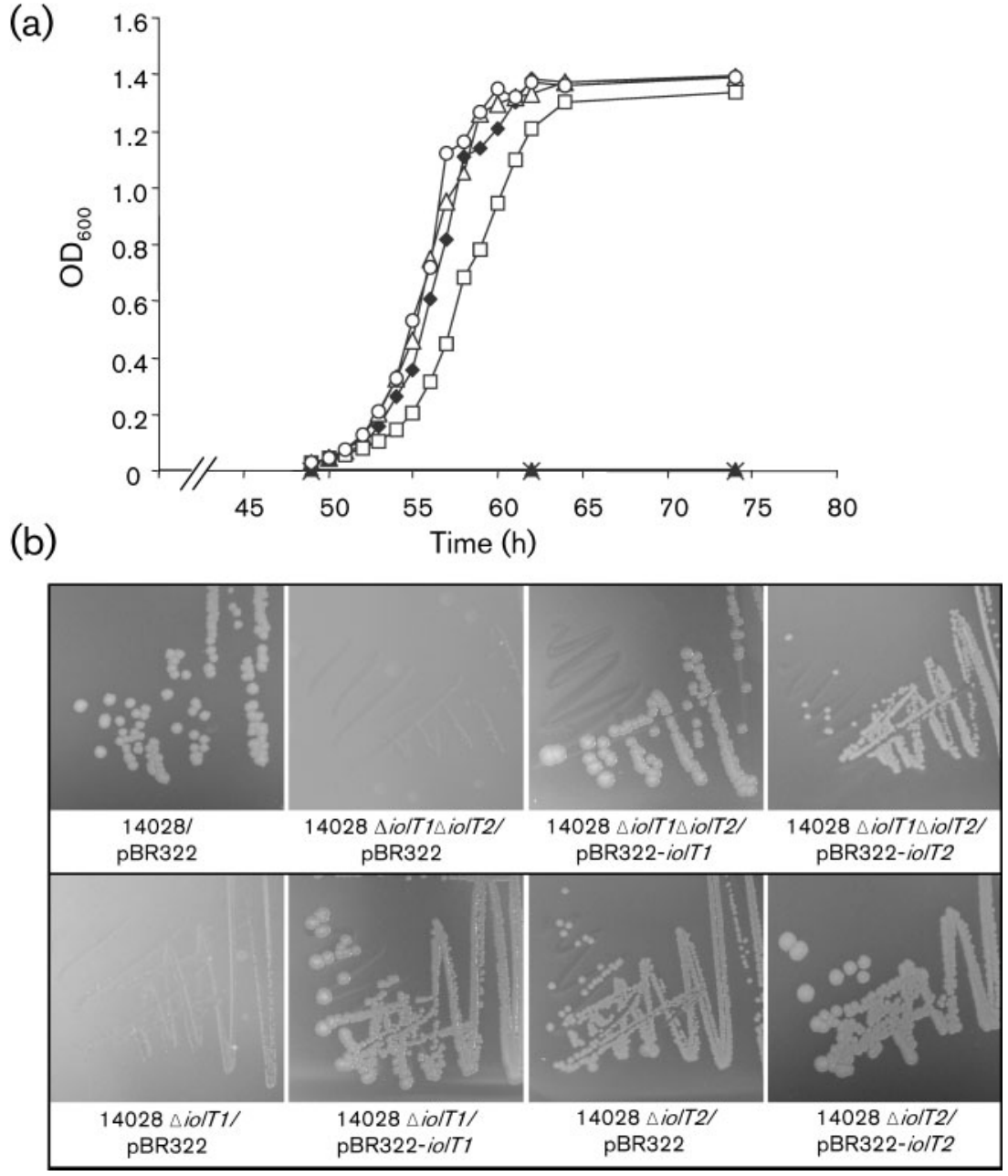

Fig. 1. Growth of $S$. enterica serovar Typhimurium strains in the presence of $55.5 \mathrm{mM}$ Ml. (a) Growth curves of strains in liquid MM supplemented with MI. 14028 (growth rate $\mu=0.37 \mathrm{~h}^{-1}$ ); $\square, 14028$ $\Delta$ iolT2 $\left(\mu=0.28 \mathrm{~h}^{-1}\right) ; \triangle, 14028 \Delta$ STM4428 $\left(\mu=0.38 \mathrm{~h}^{-1}\right) ; 0,14028 \Delta$ STM4434 $(\mu=$ $\left.0.42 \mathrm{~h}^{-1}\right)$. Zero growth phenotype: $\boldsymbol{\Delta}, 14028$ $\Delta i o / T 1 ; \times, 14028 \Delta i o / T 1 \Delta i o / T 2$. The average data from two independent experiments are shown. (b) Strains were streaked on MM agar plates containing $55.5 \mathrm{mM} \mathrm{Ml}$ and grown at $37{ }^{\circ} \mathrm{C}$ for 5 days. Above, strain 14028 , the double mutant $14028 \Delta i o / T 1 \Delta i o / T 2$ with plasmid pBR322, and the complementing constructs pBR322-iolT1 and pBR322-io/T2; below, deletion mutants lacking either iolT1 or iolT2. IolT1 was shown to have a bigger effect on growth with $\mathrm{Ml}$, but a significant growth defect was also observed for $14028 \Delta$ io/T2. Each mutant was complemented by providing the respective gene in trans. The scale of all photographs is identical. 
only very weak growth on solid medium after $128 \mathrm{~h}$ (Fig. 1b). The combined deletion of iolT1 and iolT2 completely abolished growth in the presence of MI (Fig. $1 \mathrm{a}, \mathrm{b})$. To unequivocally demonstrate the contribution of iolT1 to MI utilization, plasmid pBR322-iolT1 was transformed into strains $14028 \Delta$ iolT1 and $14028 \Delta$ iolT1SiolT2, resulting in wild-type-like growth of both mutants (Fig. 1b).

Only slightly reduced growth of $14028 \Delta$ iolT2 (STM4419) was observed in liquid medium, but a significant growth deficiency on solid medium was observed. Plasmid pBR322-iolT2 complemented this phenotype (Fig. 1a, b). The presence of plasmid pBR322-iolT2 only partially restored the growth behaviour of $14028 \Delta$ iolT1 1 iolT2 to that of strain 14028, and retarded growth in comparison with $14028 \Delta$ iolT1 $\Delta$ iolT2/pBR322-iolT1 was observed (Fig. 1b). Strain $14028 \Delta$ iolT1 did not grow in liquid medium even with $277.5 \mathrm{mM} \mathrm{MI}$, nor with plasmid pBR322-iolT2, indicating that iolT2 does not provide sufficient substrate for growth under these conditions for as yet unknown reasons.

We also tested the growth of mutants $14028 \Delta$ iolT1 and $14028 \Delta$ iolT2 in the presence of other carbon sources, namely fructose, xylose, glucose, arabinose, sorbitol and glycerol, but did not observe significant growth differences between the mutants and strain 14028 (data not shown). These results show that iolT1 and iolT2 are both involved in MI utilization and that iolT1 appears to make the bigger contribution. In contrast, STM4428 and STM4434 do not contribute to growth on MI, at least under the conditions examined here.

\section{Expression and regulation of genes involved in MI transport}

In order to investigate the regulation of iolT1 and iolT2, the $300 \mathrm{bp}$ upstream sequence of each gene was cloned into vector pDEW201, which contains the lux operon of Photorhabdus luminescens. The promoter sequence of argS encoding arginyl-tRNA synthase and a $350 \mathrm{bp}$ intragenic fragment of STM0047 lacking any promoter homology served as controls. All recombinant constructs, as well as pDEW201, were transformed into strain 14028. The optical density and the bioluminescence of the strains were measured during growth in MM supplemented with glucose or MI (Table 2). The background level determined from the control construct with the intragenic fragment 'STM0047' ranged from $2.19 \times 10^{4}$ to $2.41 \times 10^{4} \mathrm{RLU}$ per $\mathrm{OD}_{600}$ unit under all conditions tested. In $\mathrm{MM}$ with $27.8 \mathrm{mM}$ glucose, the upstream region of iolT2 resulted in light emission only slightly above the background $\left(3.38 \times 10^{4}\right.$ RLU per $\mathrm{OD}_{600}$ unit), while the predicted iolT1 promoter showed a maximal bioluminescence of $8.52 \times 10^{5} \mathrm{RLU}$ per $\mathrm{OD}_{600}$ unit. When glucose was replaced by MI, a 13.5-fold $\left(\mathrm{P}_{\text {iolT1 }}\right)$ and a 22.2 -fold $\left(\mathrm{P}_{\text {iolT2 }}\right)$ induction was observed. These data indicate that $S$. enterica serovar Typhimurium adapts to the presence of MI by increasing the amount of specific transporters whose expression is repressed in the absence of MI.

Because several promoters of genes involved in MI utilization by $S$. enterica serovar Typhimurium are negatively regulated by the repressor IolR, the pDEW201 constructs were also tested in strain $14028 \Delta$ iolR during growth in MM containing glucose (Table 1). The lack of IolR increased the transcriptional activity of $\mathrm{P}_{\text {iolT1 }}$ and of $\mathrm{P}_{\text {iolT2 }}$ by factors of 11.2 and 42.6, respectively, thus resembling the expression pattern for both transporters in the presence of MI. Therefore, the expression of iolT1 and iolT2 is probably repressed by IolR when $S$. enterica serovar Typhimurium is grown in a rich medium.

\section{The repressor loIR binds to the promoters of iolT1 and iolT2}

To strengthen the hypothesis that IolR acts as a repressor of $\mathrm{P}_{\text {iolT1 }}$ and $\mathrm{P}_{\text {iolT2 }}$, as has already been shown for the promoters of iolA, iolC1, iolD1 and iolR (Kröger \& Fuchs, 2009), its binding to the iolT1 and iolT2 promoter regions

Table 2. Quantification of promoter activities of the Ml transporter genes iolT1 and iolT2

Samples were taken from the late exponential phase corresponding to maximal promoter activity.

\begin{tabular}{|c|c|c|c|c|c|c|c|c|}
\hline \multirow[t]{2}{*}{$\begin{array}{l}\text { Fragment cloned into } \\
\text { pDEW201 }\end{array}$} & \multicolumn{2}{|c|}{$\begin{array}{l}14028 \text { grown in } \\
M M+\text { glucose }\end{array}$} & \multicolumn{3}{|c|}{14028 grown in $M M+M I$} & \multicolumn{3}{|c|}{$14028 \Delta i o l R$ grown in $\mathrm{MM}+$ glucose } \\
\hline & $\begin{array}{c}\text { RLU per } \\
\text { OD }_{600} \text { unit }^{\star}\end{array}$ & SD (\%) & $\begin{array}{c}\text { RLU per } \\
\text { OD }_{600} \text { unit }^{\star}\end{array}$ & SD (\%) & $\begin{array}{c}\text { Fold } \\
\text { induction }^{\dagger}\end{array}$ & $\begin{array}{c}\text { RLU per } \\
\text { OD }_{600} \text { unit }^{*}\end{array}$ & SD (\%) & $\begin{array}{c}\text { Fold } \\
\text { induction }^{\dagger}\end{array}$ \\
\hline $\mathrm{P}_{\text {iolT1 }}$ & $8.52 \times 10^{5}$ & 1.4 & $1.15 \times 10^{7}$ & 3.8 & 13.5 & $9.57 \times 10^{6}$ & 18.6 & 11.2 \\
\hline $\begin{array}{l}\mathrm{P}_{\text {iolT2 }} \\
\text { Controls }\end{array}$ & $3.38 \times 10^{4}$ & 18.1 & $7.50 \times 10^{5}$ & 7.6 & 22.2 & $1.44 \times 10^{6}$ & 4.9 & 42.6 \\
\hline $\mathrm{P}_{\text {args }}$ & $3.62 \times 10^{6}$ & 4.1 & $3.42 \times 10^{6}$ & 3.9 & 0.94 & $3.16 \times 10^{6}$ & 18.5 & 0.87 \\
\hline 'STM0047’ & $2.41 \times 10^{4}$ & 10.4 & $2.19 \times 10^{4}$ & 14.8 & 0.91 & $2.21 \times 10^{4}$ & 4.7 & 0.92 \\
\hline None & $4.36 \times 10^{3}$ & 43.6 & $2.33 \times 10^{3}$ & 13.7 & 0.53 & $1.60 \times 10^{3}$ & 31.5 & 0.37 \\
\hline
\end{tabular}

*Data are the mean RLU derived from three independent experiments.

${ }^{\dagger}$ Fold induction was calculated with respect to the RLU per $\mathrm{OD}_{600}$ unit values of strain 14028 grown in glucose. 
was tested by GMS assays. For that purpose, IolR was overexpressed in E. coli BL21 (DE3) and purified. PCR products containing the putative promoters of iolR, iolT1, iolT2 and iolH were incubated with or without increasing amounts of the purified IolR protein, and the proteinDNA complexes were separated on $9.5 \%$ native polyacrylamide gels. A DNA band with decreased motility representing the IolR-DNA complex was observed with the iolT1 and iolT2 fragments, indicating that IolR binds to the promoter elements of these two MI transporter genes (Fig. 2). Binding of IolR to its own promoter served as a positive control, and complex formation was not observed with a fragment located upstream of iolH encoding a protein that is not required for MI degradation (Kröger \& Fuchs, 2009). Together with the transcriptional analysis described above, these data demonstrate that IolR is a DNA-binding protein that negatively regulates the expression of iolT1 and iolT2 during growth of S. enterica serovar Typhimurium in a medium lacking MI. A conserved motif in the upstream regions of the two genes could not be identified.

\section{IolT1 mediates MI uptake when expressed in E. coli}

IolT1 and IolT2, with molecular masses of 53.4 and $52.1 \mathrm{kDa}$, respectively, appear to be typical members of the MFS (Law et al., 2008), and are predicted to possess 12 transmembrane (TM) domains by multiple prediction algorithms. Since E. coli DH5 $\alpha$ is not able to grow on MI, a finding that is in line with the absence of iol genes in the genome of $E$. coli $\mathrm{K}-12$, it was chosen for heterologous expression of IolT1 and IolT2 to study their MI transport activity. E. coli DH5 $\alpha$ cells were transformed with pBR322iolT1 and pBR322-iolT2, and uptake assays were performed as detailed in Methods. In a first experiment, DH5 $\alpha$ cells expressing IolT1 or IolT2 were compared with cells containing an empty plasmid. The assays were performed with an initial extracellular MI concentration of $1 \mathrm{mM}$, which is higher than the $K_{\mathrm{m}}$ value of the related $\mathrm{MI}$ transporters from C. glutamicum (Krings et al., 2006). IolT1-expressing cells showed high levels of MI uptake, which were linear for $50 \mathrm{~s}$ after substrate addition (Fig. 3a)
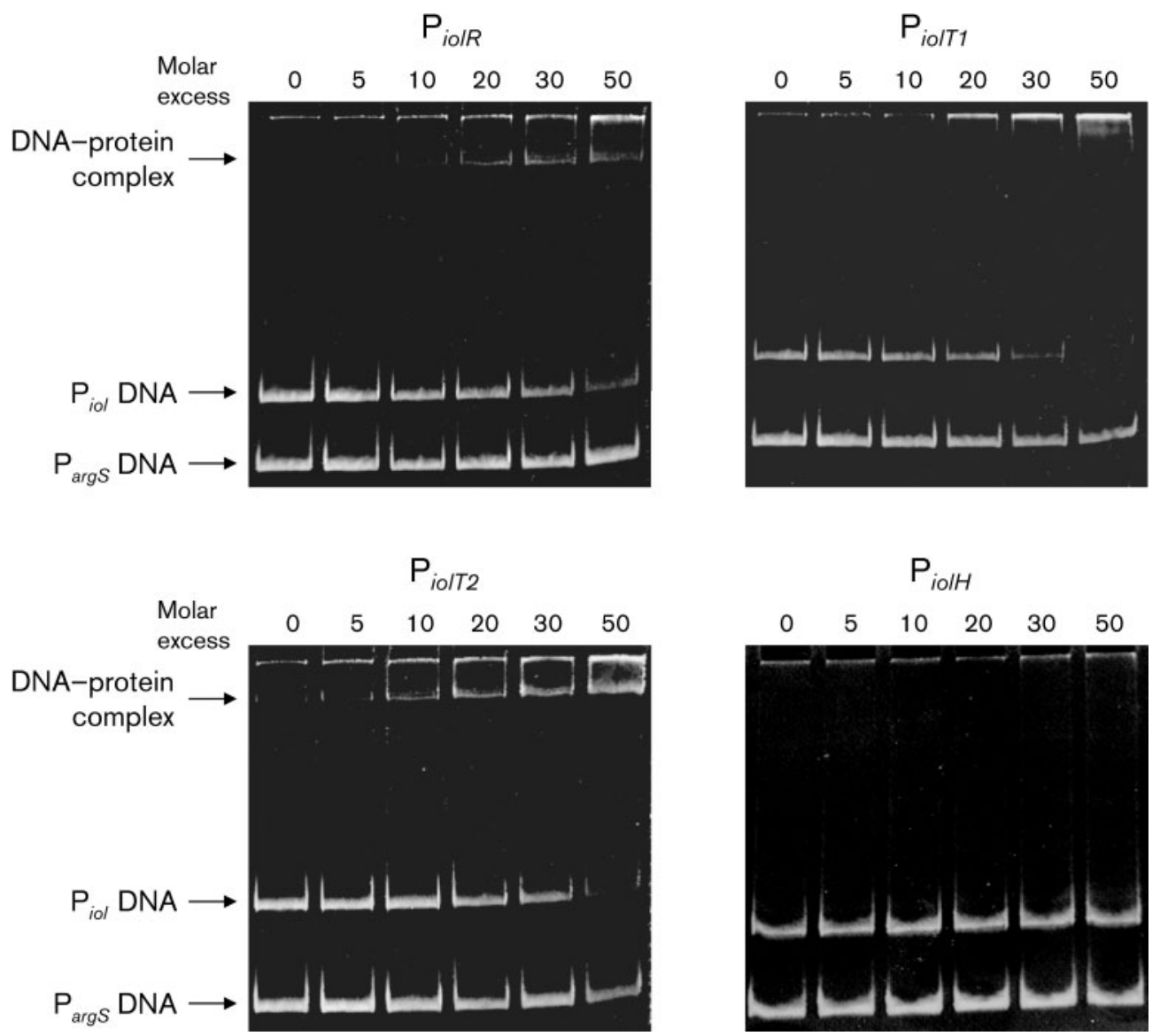

Fig. 2. GMS assays to study DNA binding activity of loIR. The interaction of lolR with the promoter region of four genes of GEI $4417 / 4436$ is shown. Promoter DNA (100 ng) was incubated with or without increasing amounts $(81,162,324,678$ and $810 \mathrm{ng}$ ) of purified loIR. Protein-DNA complexes were separated on $9.5 \%$ native polyacrylamide gels. As a control, $100 \mathrm{ng}$ competitor DNA comprising the argS promoter was added. 




(b)

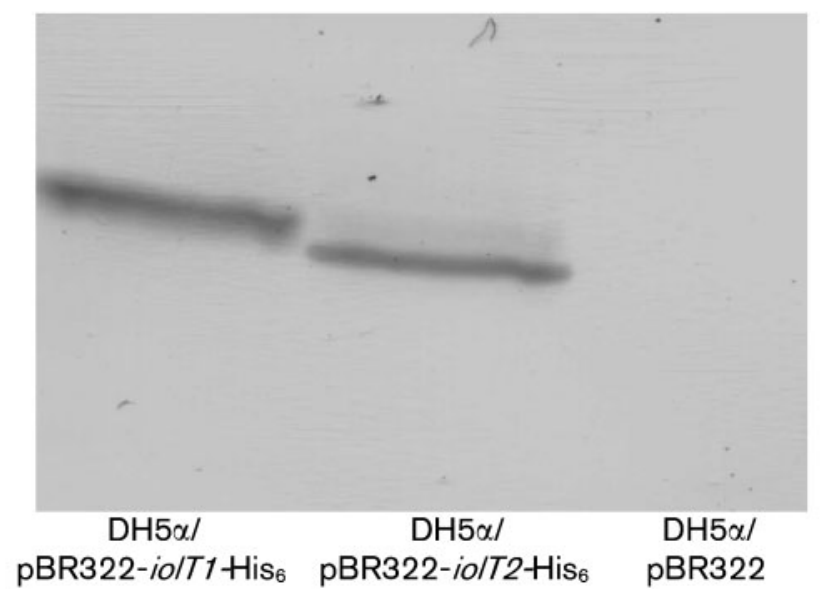

Fig. 3. Ml uptake by heterologously expressed lolT1 and lolT2. (a) E. coli DH5 $\alpha$ cells containing plasmids pBR322-io/T1 ( $)$, pBR322iolT2 ( $\square$ ) or pBR322 ( $\times$; negative control) were grown in LB medium, harvested by centrifugation, resuspended in Mcllvaine's buffer $(\mathrm{pH} 5.5)$ at $\mathrm{OD}_{600} 4.0$ and energized by the addition of $55.5 \mathrm{mM}$ glucose (final concentration). The uptake experiment was started by the addition of a mixture of $1 \mathrm{mM} \mathrm{Ml}$ and $26.67 \mathrm{nM} \quad m y o-\left[1,2-\left[{ }^{3} \mathrm{H}\right](\mathrm{N})\right]$ inositol. Aliquots of the cell suspension were taken 10,30 and $50 \mathrm{~s}$ after the addition of MI. In experiments with DH5 $\alpha /$ pBR322-io/T1 $(\diamond)$, the protonophore CCCP was added $2 \mathrm{~min}$ before starting the uptake experiment. (b) Membrane localization of lolT1-His ${ }_{6}$ and lolT2-His ${ }_{6}$. For each sample, $15 \mu \mathrm{g}$ membrane protein was subjected to SDS-PAGE and Western blot analysis using monoclonal anti-His $_{6}$ antibodies. The samples were obtained from $E$. coli $\mathrm{DH} 5 \alpha$ cells containing pBR322-io/T1-His ${ }_{6}$ (left), pBR322-io/T2-His 6 (centre) or pBR322 (right, negative control). and levelled off at later time points (data not shown). This uptake activity was drastically reduced in the presence of the protonophore CCCP (Fig. 3a). In contrast to IolT1producing cells, cells expressing IolT2 did not significantly differ from vector controls and showed no MI uptake (Fig. 3a). This situation did not change even when this experiment was continued for up to $2.5 \mathrm{~h}$, nor in the presence of $2 \mathrm{mM} \mathrm{MI}$ at higher specific activity (data not shown).

To verify that the transformation of the two plasmids had led to the production and cytoplasmic membrane insertion of the IolT proteins, similar plasmids were constructed in which the reading frames of the two genes were extended by a C-terminal His-tag. Both transporter genes were transcribed from their own promoters. Membrane extracts from the transformed cells were separated by SDS-PAGE, blotted onto a nitrocellulose membrane and probed with monoclonal anti-His ${ }_{6}$ antibodies. Two bands, corresponding to IolT1 and IolT2, were revealed that were absent in the control strain with pBR322 (Fig. 3b). This analysis showed that the promoters of iolT1 and iolT2 are active in E. coli, leading to the production of both proteins at similar levels, and that they are inserted into the E. coli membrane. Thus, the lack of inositol uptake in IolT2-expressing cells is unlikely to be caused by a lack of gene expression.

\section{pH optimum and kinetic properties of lolT1- dependent MI transport}

We continued with the analysis of the IolT1 activity and determined its $\mathrm{pH}$ optimum by performing uptake assays at various external $\mathrm{pH}$ values. The IolT1-driven MI uptake displayed a sharp $\mathrm{pH}$ optimum with a maximum at $\mathrm{pH} 5.5$, and significantly reduced uptake rates at higher or lower $\mathrm{pH}$ (Fig. 4a). Together with the inhibition of MI uptake by CCCP (Fig. 3a), this indicates that IolT1 operates as an $\mathrm{MI} /$ proton symporter.

To determine the kinetic properties of IolT1-dependent MI uptake by $S$. enterica serovar Typhimurium, transport assays were performed at $\mathrm{pH} 5.5$ with varying amounts of substrate. The uptake of MI was saturable, and a $K_{\mathrm{m}}$ value of $0.79 \mathrm{mM}$ was determined. The Eadie-Hofstee plot of these data provides no indication that two kinetically different proteins contribute to MI uptake by $S$. enterica serovar Typhimurium (Fig. 4b). A similar $K_{\mathrm{m}}$ value $(0.49 \mathrm{mM})$ was obtained with strain $14028 \Delta$ iolT2 (data not shown), again demonstrating the bigger contribution of IolT1 to MI uptake. To exclude the possibility that the presence of $1 \%$ glucose used for cell energizing had a detrimental effect on MI transport, the experiment was 


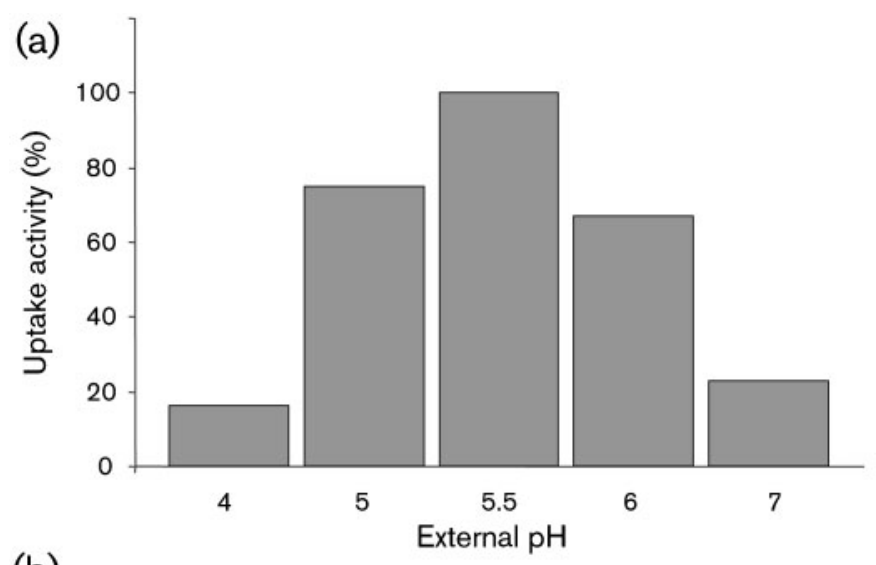

(b)

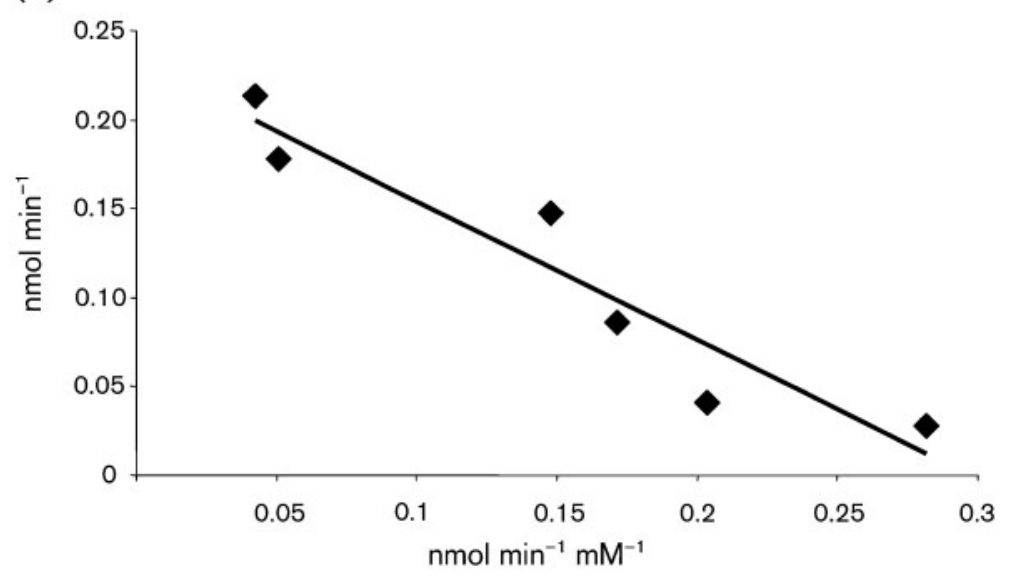

Fig. 4. $\mathrm{pH}$ optimum and saturation kinetics of lolT1-mediated Ml uptake. The uptake assays were performed as described in the legend to Fig. 3. (a) Determination of the $\mathrm{pH}$ optimum of Ml uptake with DH5 $\alpha /$ pBR322-io/T1. The cells were resuspended in Mcllvaine's buffer at the indicated $\mathrm{pH}$ values. The figure shows the result of one of three repetitions that all confirmed the $\mathrm{pH}$ optimum to be $\mathrm{pH}$ 5.5. (b) Eadie-Hofstee plot of an Ml uptake experiment with $S$. enterica serovar Typhimurium strain 14028. Substrate concentrations were $5,3.5$, $1,0.5,0.2$ and $0.1 \mathrm{mM}$. A $K_{\mathrm{m}}$ value of $0.79 \mathrm{mM}$ was calculated from three measurements. performed with strain 14028 in the absence of glucose, but no significant differences were observed (data not shown). In experiments with heterologously expressed IolT1, $K_{\mathrm{m}}$ values of $0.71,0.51$ and $0.38 \mathrm{mM}$ were calculated, resulting in an average $K_{\mathrm{m}}$ value of $0.53 \pm 0.2 \mathrm{mM}$ for IolT1 expressed in E. coli. Taken together, IolT1 appears to be the predominant MI transporter of $S$. enterica serovar Typhimurium, with functional similarities to the two characterized MI facilitators of C. glutamicum (Krings et al., 2006).

\section{lolT1-like proteins involved in MI utilization}

According to genome sequence data, a large number of bacteria carry genes with homology to iol genes, including Brucella abortus, Photobacter profundum, Yersinia spp., Citrobacter koseri and Erwinia carotovora. Genetic comparison and computational analysis of iol divergons have been performed recently (Boutte et al., 2008; Kröger \& Fuchs, 2009). A phylogenetic analysis of iol genes from L. casei is also available (Yebra et al., 2007). We investigated whether, and to what degree of similarity, IolT homologues are present in other bacterial genomes. IolT1 and IolT2 of $S$. enterica serovar Typhimurium exhibit an identity of $44 \%$ and a similarity of $66 \%$ over the whole protein length. No significant sequence identity was found between the two predicted permeases STM4428 or STM4434, or between either protein and IolT1 or IolT2. Homology searches using BLAST (Altschul et al., 1997) revealed many uncharacterized bacterial proteins with significant similarity to IolT1, among them the major MI transporter of $B$. subtilis, IolT, with an identity of $33 \%$. A cladogram of a representative selection of these proteins, many of which are annotated as putative xylose transporters, is shown in Fig. 5. The IolT1 homologues of E. coli ED1a, Yersinia frederiksenii, Serratia proteamaculans, Vibrio shiloi, $P$. profundum and Azotobacter vinelandii are clustered with the genes involved in MI degradation, suggesting an MI transport function for these proteins. The IolT homologues of several species unable to utilize MI, such as E. coli, Vibrio angustum, Photobacterium sp. and Paenibacillus sp., are also grouped, indicating that these proteins transport other sugars or sugar alcohols. Interestingly, the Bacillus cereus IolT1 homologue of this group is not identical to the major MI transporter of B. subtilis (Yoshida et al., 2002), but is more closely related to homologues from Gram-negative species. On the other hand, IolT1 homologues of Yersinia intermedia, Yersinia enterocolitica and Klebsiella pneumoniae are more closely related to transporter proteins of Gram-positive bacteria, making it difficult to trace the evolutionary origin of iolT1 and the gene clusters it belongs to. The most distantly related group comprises IolT1 


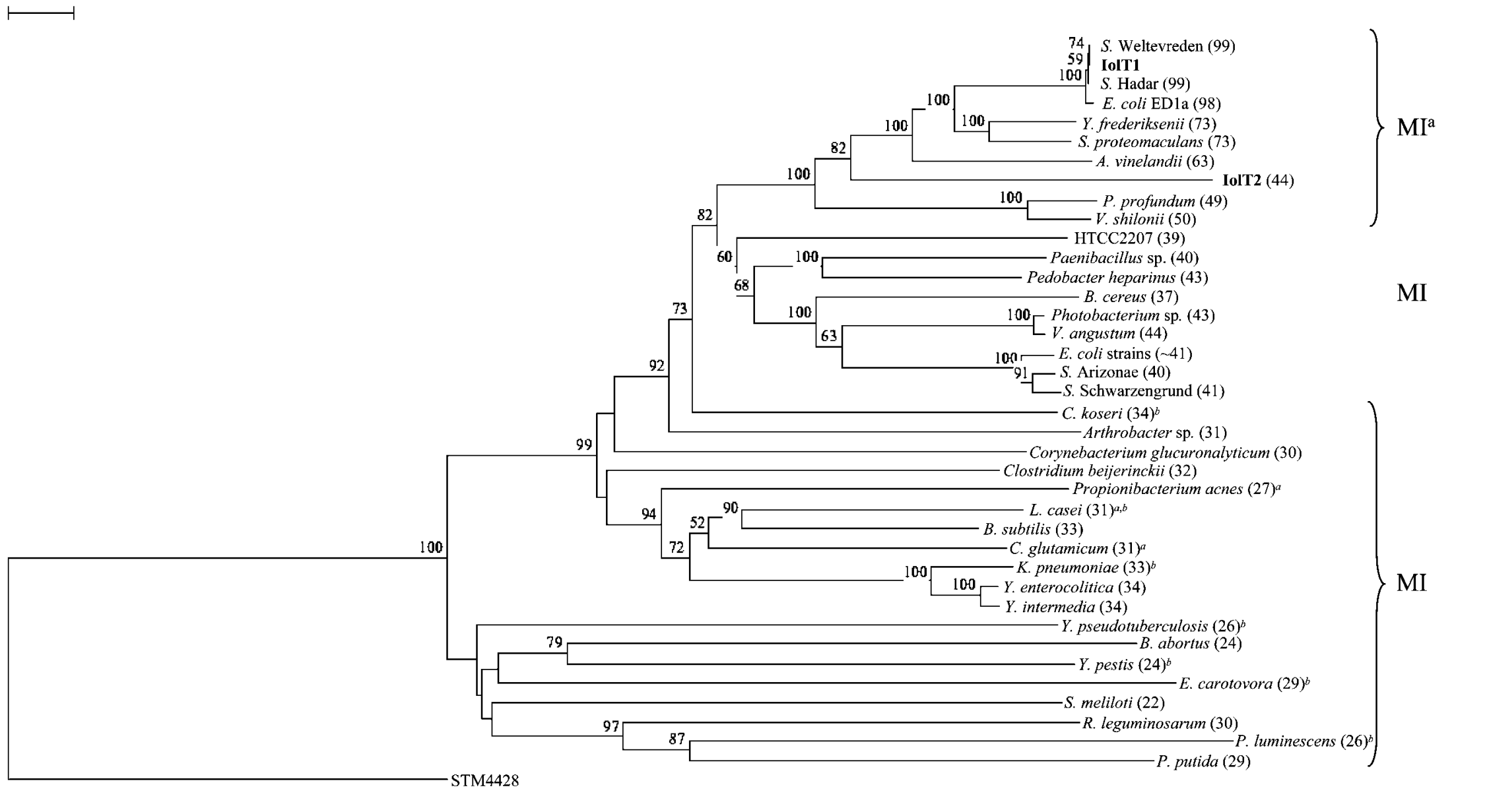

Fig. 5. Cladogram based on 37 proteins with homology to lolT1 of $S$. enterica serovar Typhimurium. Percentage identities are indicated in parentheses. The putative permease STM4428 served as the outgroup. The phylogenetic analysis was performed with the neighbour-joining method and calculated using the Poisson correction. Values on each branch indicate the occurrence (\%) of the branching order in 500 bootstrapped trees. Bar, $10 \%$ sequence divergence. HTCC2207 is a marine $\gamma$-proteobacterium. Ml, capability of utilizing Ml or presence of io/ genes in the genome. lolT1 and lolT2 are labelled in bold type. ${ }^{a}$ The lolT1 homologue is clustered with the genes of the iol divergon; ${ }^{b}$ other putative permeases are present within the iol gene cluster. 
homologues of species such as Yersinia pseudotuberculosis, Yersinia pestis, Erwinia carotovora and P. luminescens. These homologues are located outside the iol divergons, which carry genes encoding permeases, suggesting as yet unknown MI transporters in these bacteria. Consistent with this interpretation, Boutte et al. (2008) identified an ABC transporter for MI in Sinorhizobium meliloti and five other $\alpha$-proteobacteria, thus defining a novel class of MI facilitators.

\section{DISCUSSION}

Of the four permeases located within GEI4417/4436, two were identified as MI transporters of S. enterica serovar Typhimurium and termed IolT1 and IolT2. While deletion of iolT1 severely affected growth of strain 14028, only a slight growth deficiency was observed when $14028 \Delta$ iolT2 was grown in liquid MM containing MI (Fig. 1a). Two MI transporters with major and minor transport activity have also been identified in B. subtilis and C. glutamicum (Krings et al., 2006; Yoshida et al., 2002). In B. subtilis, the minor transporter IolF has been shown to have a lower substrate affinity than that of IolT, and IolF can support growth on MI only partially. The double deletion mutant $14028 \Delta$ iolT1 1 iolT2 could be complemented by providing iolT2 in trans only on solid, but not in liquid medium. No significant MI transport activity of IolT2 could be detected in uptake experiments with E. coli. In C. glutamicum, the two MI transporters IolT1 and IolT2 have similar kinetic properties and a sequence identity of $55 \%$. Overexpression of iolT1 and iolT2 of the same organism leads to a twofold increase of the D-fructose uptake rate, but both transporters show a lower specificity towards this sugar than towards MI (Bäumchen et al., 2009). However, an apparent growth defect of iolT mutants of $B$. subtilis or S. enterica serovar Typhimurium in the presence of a variety of sugars has not been observed (Yoshida et al., 2002). A major difference between MI utilization by Gram-positive bacteria and that of $S$. enterica serovar Typhimurium is the extended lag phase of this Gram-negative pathogen in medium containing MI as sole carbon and energy source (Fig. 1a). The molecular mechanism underlying this growth retardation by at least 2 days is not yet completely understood. The lag phase has been shown to be shortened by approximately $10 \mathrm{~h}$ in an iolR deletion mutant, indicating a key role of IolR in this phenomenon (Kröger \& Fuchs, 2009). The binding of a cofactor or an intermediate of MI degradation to IolR, or an external signal, might release the tight repression of iol genes in $S$. enterica serovar Typhimurium.

Luciferase reporter assays revealed IolR to be a repressor of iolT1 and iolT2 transcription (Table 2). The absolute RLU per OD unit values show that in MM with MI, iolT1 is expressed to an approximately 15 -fold higher degree than iolT2. When both transporter genes were overexpressed in E. coli, similar protein levels were detected by Western blot analysis (Fig. 3b), but the MI transport activity of IolT2 was not detectable. Because IolT2 appears to have a significantly lower molecular mass than IolT1, it might be assumed that IolT2 is misfolded in the E. coli membrane or degraded to a stable yet inactive form. Also, it cannot be excluded that IolT2 activity requires different assay conditions. However, the tests performed in S. enterica serovar Typhimurium strongly indicate that IolT2 supports growth on MI, albeit with a longer generation time. This and the fact that the putative minor transporter IolT2 supports growth of $S$. enterica serovar Typhimurium on solid medium only are in contrast to findings in B. subtilis and C. glutamicum. It is possible that the preferred substrate of IolT2 is an unknown, MI-related compound or MI catabolite and that MI does not represent the physiologically relevant substrate of the protein (Reber et al., 1977). The $K_{\mathrm{m}}$ values of 0.49 and $0.79 \mathrm{mM}$ reported here for IolT1 of $S$. enterica serovar Typhimurium are similar to those of the major MI transporters in B. subtilis (0.15 mM, IolT) and C. glutamicum (0.33/0.45 mM, IolT1/ IolT2). In S. enterica serovar Typhimurium, the transcriptional activities of the iolT1 and iolT2 promoters are approximately 10-40-fold induced in the presence of MI, or upon deletion of the repressor gene iolR. This pattern is similar to the results of iolT: : lac $Z$ fusion assays performed with B. subtilis under similar growth conditions (Yoshida et al., 2002). Together with the finding that the expression of MI transporters is negatively controlled by IolR, these data indicate a highly conserved regulatory mechanism of MI transporter expression in Gram-positive and Gram-negative bacteria.

Taken together, the growing number of iol gene sequences and of bacterial species able to grow on MI revealed a high variation of gene content, genetic organization and functionality, while several aspects of MI utilization still remain to be discovered. Open questions regarding MI metabolism that are currently addressed in S. enterica serovar Typhimurium are further regulatory mechanisms contributing to MI utilization, the identification of MIrelated substrates metabolized by the Iol enzymes, and the relevance of this pathway in vivo.

\section{ACKNOWLEDGEMENTS}

We thank Siegfried Scherer for financial support of this study. Patrick Schiwek is acknowledged for technical assistance, and Gabor Kottra for help with data analysis.

\section{REFERENCES}

Altschul, S. F., Madden, T. L., Schaffer, A. A., Zhang, J., Zhang, Z., Miller, W. \& Lipman, D. J. (1997). Gapped BLAST and PSI-BLAST: a new generation of protein database search programs. Nucleic Acids Res 25, 3389-3402.

Anderson, W. A. \& Magasanik, B. (1971). The pathway of myoinositol degradation in Aerobacter aerogenes. Conversion of 2-deoxy5-keto-D-gluconic acid to glycolytic intermediates. J Biol Chem 246, $5662-5675$. 
Bäumchen, C., Krings, E., Bringer, S., Eggeling, L. \& Sahm, H. (2009). myo-Inositol facilitators IolT1 and IolT2 enhance D-mannitol formation from D-fructose in Corynebacterium glutamicum. FEMS Microbiol Lett 290, 227-235.

Berman, T. \& Magasanik, B. (1966). The pathway of myo-inositol degradation in Aerobacter aerogenes. Ring scission. J Biol Chem 241, 807-813.

Boutte, C. C., Srinivasan, B. S., Flannick, J. A., Novak, A. F., Martens, A. T., Batzoglou, S., Viollier, P. H. \& Crosson, S. (2008). Genetic and computational identification of a conserved bacterial metabolic module. PLoS Genet 4, e1000310.

Bradford, M. M. (1976). A rapid and sensitive method for the quantitation of microgram quantities of protein utilizing the principle of protein-dye binding. Anal Biochem 72, 248-254.

Datsenko, K. A. \& Wanner, B. L. (2000). One-step inactivation of chromosomal genes in Escherichia coli K-12 using PCR products. Proc Natl Acad Sci U S A 97, 6640-6645.

Fry, J., Wood, M. \& Poole, P. S. (2001). Investigation of myo-inositol catabolism in Rhizobium leguminosarum bv. viciae and its effect on nodulation competitiveness. Mol Plant Microbe Interact 14, 10161025.

Gauchat-Feiss, D., Frey, J., Belet, M. \& Deshusses, J. (1985). Cloning of genes involved in myo-inositol transport in a Pseudomonas sp. J Bacteriol 162, 324-327.

Hanahan, D. (1983). Studies on transformation of Escherichia coli with plasmids. J Mol Biol 166, 557-580.

Kawsar, H. I., Ohtani, K., Okumura, K., Hayashi, H. \& Shimizu, T. (2004). Organization and transcriptional regulation of myo-inositol operon in Clostridium perfringens. FEMS Microbiol Lett 235, 289-295.

Klumpp, J. \& Fuchs, T. M. (2007). Identification of novel genes in genomic islands that contribute to Salmonella typhimurium replication in macrophages. Microbiology 153, 1207-1220.

Kreutzenbeck, P., Kröger, C., Lausberg, F., Blaudeck, N., Sprenger, G. A. \& Freudl, R. (2007). Escherichia coli twin arginine (Tat) mutant translocases possessing relaxed signal peptide recognition specificities. J Biol Chem 282, 7903-7911.

Krings, E., Krumbach, K., Bathe, B., Kelle, R., Wendisch, V. F., Sahm, H. \& Eggeling, L. (2006). Characterization of myo-inositol utilization by Corynebacterium glutamicum: the stimulon, identification of transporters, and influence on L-lysine formation. J Bacteriol 188, 8054-8061.

Kröger, C. \& Fuchs, T. M. (2009). Characterization of the myo-inositol utilization island of Salmonella enterica serovar Typhimurium. $J$ Bacteriol 191, 545-554.

Law, C. J., Maloney, P. C. \& Wang, D. N. (2008). Ins and outs of major facilitator superfamily antiporters. Annu Rev Microbiol 62, 289-305.

Legakis, N. J., Papavassiliou, J. T. \& Xilinas, M. E. (1976). Inositol as a selective substrate for the growth of klebsiellae and serratiae. Zentralbl Bakteriol Orig A 235, 453-458.
Link, A. J., Phillips, D. \& Church, G. M. (1997). Methods for generating precise deletions and insertions in the genome of wild-type Escherichia coli: application to open reading frame characterization. J Bacteriol 179, 6228-6237.

Mcllvaine, T. C. (1921). A buffer solution for colorimetric comparison. J Biol Chem 49, 183-186.

Miwa, Y. \& Fujita, Y. (2001). Involvement of two distinct cataboliteresponsive elements in catabolite repression of the Bacillus subtilis myo-inositol (iol) operon. J Bacteriol 183, 5877-5884.

Primrose, S. B. \& Ronson, C. W. (1980). Polyol metabolism by Rhizobium trifolii. J Bacteriol 141, 1109-1114.

Reber, G., Belet, M. \& Deshusses, J. (1977). myo-Inositol transport system in Pseudomonas putida. J Bacteriol 131, 872-875.

Sambrook, J. \& Russell, D. W. (2001). Molecular Cloning: a Laboratory Manual, 3rd edn. Cold Spring Harbor, NY: Cold Spring Harbor Laboratory.

Schaaf, S. \& Bott, M. (2007). Target genes and DNA-binding sites of the response regulator PhoR from Corynebacterium glutamicum. J Bacteriol 189, 5002-5011.

Studier, F. W., Rosenberg, A. H., Dunn, J. J. \& Dubendorff, J. W. (1990). Use of T7 RNA polymerase to direct expression of cloned genes. Methods Enzymol 185, 60-89.

Van de Peer, Y. \& De Wachter, R. (1994). TREECON for Windows: a software package for the construction and drawing of evolutionary trees for the Microsoft Windows environment. Comput Appl Biosci 10, 569-570.

Van Dyk, T. K. \& Rosson, R. A. (1998). Photorhabdus luminescens luxCDABE promoter probe vectors. Methods Mol Biol 102, 85-95.

Yebra, M. J., Zuniga, M., Beaufils, S., Perez-Martinez, G., Deutscher, J. \& Monedero, V. (2007). Identification of a gene cluster enabling Lactobacillus casei BL23 to utilize myo-inositol. Appl Environ Microbiol 73, 3850-3858.

Yoshida, K. I., Aoyama, D., Ishio, I., Shibayama, T. \& Fujita, Y. (1997). Organization and transcription of the myo-inositol operon, iol, of Bacillus subtilis. J Bacteriol 179, 4591-4598.

Yoshida, K. I., Shibayama, T., Aoyama, D. \& Fujita, Y. (1999). Interaction of a repressor and its binding sites for regulation of the Bacillus subtilis iol divergon. J Mol Biol 285, 917-929.

Yoshida, K., Yamamoto, Y., Omae, K., Yamamoto, M. \& Fujita, Y. (2002). Identification of two myo-inositol transporter genes of Bacillus subtilis. J Bacteriol 184, 983-991.

Yoshida, K., Yamaguchi, M., Ikeda, H., Omae, K., Tsurusaki, K. \& Fujita, Y. (2004). The fifth gene of the iol operon of Bacillus subtilis, iolE, encodes 2-keto-myo-inositol dehydratase. Microbiology 150, 571580.

Yoshida, K., Yamaguchi, M., Morinaga, T., Kinehara, M., Ikeuchi, M., Ashida, H. \& Fujita, Y. (2008). myo-Inositol catabolism in Bacillus subtilis. J Biol Chem 283, 10415-10424.

Edited by: G. H. Thomas 